\title{
Assessment of the Levels of Herbicide Residues in Fish Samples from Alau Dam, Maiduguri, Borno, State, Nigeria
}

\author{
Joseph Clement Akan*, Lawan Bukar Inuwa, Zaynab Muhammad Chellube, \\ Musa Muhammad Mahmud, Fanna Inna Abdulrahman
}

Department of Chemistry, University of Maiduguri, Maiduguri, Nigeria

Email address:

joechemakan@yahoo.com (J. C. Akan)

To cite this article:

Joseph Clement Akan, Lawan Bukar Inuwa, Zaynab Muhammad Chellube, Musa Muhammad Mahmud, Fanna Inna Abdulrahman. Assessment of the Levels of Herbicide Residues in Fish Samples from Alau Dam, Maiduguri, Borno, State, Nigeria. International Journal of Environmental Chemistry. Vol. 3, No. 2, 2019, pp. 53-58. doi: 10.11648/j.ijec.20190302.11

Received: March 11, 2019; Accepted: May 15, 2019; Published: December 20, 2019

\begin{abstract}
The aim of this study is to determine the levels of atrazine, propanil, alachlor, metolachlor, paraquat, propachlor, butachlor and glysophate in the flesh, liver, intestine and gills of Tilapia zilli, Clarias anguillaris, Synodentis budgetti and Heterotis niloticus from Alau Dam The highest total concentrations of all the studied herbicide residues were detected in Tilapia zillii, follow by Clarias anguillaris, while Synodentis budgetti shows the lowest values. The highest concentrations of all the herbicide residues were detected in the liver of Tilapia zilli and Clarias angullaris while Synodentis budgetti shows the lowest value. Also, the flesh and gills of Tilapia zilli was observed to show the highest levels of all the studied herbicides, while Clarias angullaris shows the lowest value. The values observed for herbicide residues were lower than the WHO and FAO set maximum residue limit (MRL) $0.01 \mathrm{mg} / \mathrm{kg}$ and the Acceptable Daily Intake value (ADI) of $0.006 \mathrm{mg} / \mathrm{kg}$ which is considered safe for consumption as at the time of the present research work. But their presence in the fish samples also cause for concern, therefore, it is important for relevant agencies to be involve in the management of Alau Dam with respect to herbicide residues.
\end{abstract}

Keyword: Fish, Herbicide, Residues, Organs, MRL, ADI

\section{Introduction}

The application of herbicides is a routine practice for controlling harmful grass in plants. Systemic herbicides applied on crops are absorbed either by the plant roots or foliar parts and are incorporated into the tissues, and in the case of sugarcane it can result in the presence of their residues in the juice. In the wake of herbicide pollution and its detrimental effect on biodiversity, there is a lot of research towards development of affordable and quick methods without compromising the effectiveness of such in detecting and monitoring of these herbicides. Some of the deleterious effects of herbicides include carcinogenicity [1], endocrine activity [1]; and a range of other ailments such as immune suppression, diminished intelligence and reproductive abnormalities [2]. However, these chemicals are still very important in agro-industry for the control of pests and weed for increased agricultural and food production. Consequently, this poses a dilemma regarding food security on one hand and a threat to human life and biodiversity of not only amphibians, but also of other natural flora and fauna [1]. Due to these effects and many other associated issues, foods tainted with herbicides lose their competitiveness in the markets [3]. This is especially so lately when attention seems to shift towards the so-called 'organic' foods [3]. Other than the market related issues, herbicides monitoring could also aid in important issues such as planning crop rotation which sometimes could be dependent on the presence of traces of the herbicides applied in the previous season [1]. Modern agricultural practices often include the extensive use of a wide range of pesticides for increased crop production as well as for greater yield by controlling pests [4, 5]. The use of pesticides, therefore, continues to exist as world 
population and the demand for food production continues to grow. In 1995, conventional pesticide use in USA amounted about 1.22 billion pounds, which was one fifth of the world's use of such chemical [5]. In spite of the undeniable advantages that pesticides have brought to modern agricultural economy for controlling pests, they can generate a series of problems for untargeted organisms, if the necessary precautions are not taken during applications and storages [5]. Large fractions of the pesticides used in agricultural settings end up moving with surface run-off into streams, rivers and lakes, leaching to the ground water systems, or volatilize to the atmosphere [6]. As a result, residues of such compounds can be the main source of environmental pollution [7], they may be found in the soil in which the crop was grown, may also appear in the atmosphere, in run-off water following heavy rain, irrigation, in ground water or in surface water [8] and consequently, they can directly or indirectly pollute food and food products and biological systems. Agricultural chemicals, can have determinable environmental effects when applied improperly [4]. Therefore, herbicides and their potentially undesirable effects on the environment, aquatic organisms and human health has been one of the major concerns of recent research [4]. Atrazine is one of the most widely used herbicide globally, commonly used in Nigeria for the control of weeds in most farms [9]. Despite its intensive use, atrazine has been implicated in a number of health effects [10]. High concentrations of atrazine in serum and urine samples of cattle were observed [11]. Butachlor has been proven to be genotoxic and cytotoxic in catfish (Clarias gariepinus) and the concentration of butachlor was found proportional to the extent of DNA damage [12].

Alau Dam is located in Maiduguri, Borno State, Nigeria (Map 1). Alau Dam is use for commercial fishing activities and the main source of fish and vegetables to the State and neighboring States within the country. The Dam is nine meter high with a square reservoir area of about 50 square kilometer. The maximum storage capacity is 112 million meter cube. Alau Dam received water from River Yedzram and River Gombole which meet at a confluent at Sambisha and flow as River Ngada into Alau Dam. Within the two rivers, intensive agriculture activities take place couple with the used of synthetic herbicides to control weed on vegetables and other farm products. The herbicides are extensively used in agricultural production in the study area to control weeds and other plant pathogens in an effort to reduce or eliminate yield losses and preserve high product quality. But the users of these herbicides are generally untrained, have poor literacy and are not aware of the toxicity of the products they use for crop production within the study areas. This has resulted in their misuse and consequently can accumulation in soil and subsequently wash by rainfall and eventually flows into river Ngada. These residues of herbicide might be taken up and accumulated by aquatic organism including fishes, such accumulation may ultimately, adversely affect humans and other species that depend on such fishes for food. As a result of the possible effect of herbicide residues to the study area, the analysis of herbicide residues in the study area is of immense significance. Hence, the need to determine the levels of herbicide residues in different varieties of fish.

\section{Material and Methods}

\subsection{Fish Samples}

Fish samples (Tilapia zilli, Clarias anguillaris, Synodentis budgetti and Heterotis niloticus) were caught using gill nets from Alau Dam, Konduga Local Government Area, Borno State, Nigeria. Fish samples of uniform size were collected in order to avoid the possible error due to size differences. The fish were labelled with an identification number. The samples of fish were transported to the laboratory on the same day, identified by an expert in the Department of Fisheries, University of Maiduguri, and later dissected to remove the flesh, liver intestine and gills of each species of fish and preserved in a refrigerator, pending extraction and analysis.

\subsection{Extraction of Fish Samples}

For the fish samples, $50 \mathrm{~g}$ of the flesh, intestine, liver and gills of the fish from each sample was homogenized. Extraction was performed by using $150 \mathrm{ml}$ of acetonitrile. The samples were filtered and rinsed twice with $25 \mathrm{ml}$ of the acetonitrile. The combined extract were concentrated using a rotary vacuum and evaporated over a hot water bath at $30^{\circ} \mathrm{C}$ to $50 \mathrm{ml}$. The liquid - liquid partitioning was transferred into a $500 \mathrm{ml}$ separator funnel and diluted with $250 \mathrm{ml}$ of $5 \%$ aqueous sodium chloride and partitioned into 150 and $100 \mathrm{ml}$ of $\mathrm{n}$-hexane. The combined n-hexane layer was passed through anhydrous sodium sulphate and concentrated to near dryness of $10 \mathrm{ml}$-hexane as described [13].

\subsection{Determination of Herbicide Residues}

The extracts obtained from the extraction of the water, sediment and fish was thereafter analyzed using Agilent 7890A GC/ MS previously calibrated with herbicide standards. The equipment turned out the concentration of the herbicides as the sample details were supplied for the studied samples.

\section{Results}

Concentrations of Some Herbicide Residues in Different Tissues of Fish Samples

Table 1 shows the mean concentrations of herbicide residues in different tissues of Tilapia zillii. The highest total concentration of $5.56 \mathrm{E}-02 \mathrm{mg} / \mathrm{kg}$ was recorded in the liver, while the lowest total concentration of $2.31 \mathrm{E}-03 \mathrm{mg} / \mathrm{kg}$ was recorded in the intestine. Similarly, Table 2 present the concentrations of herbicide residues in different tissues of 
Clarias anguillaris from Alau Dam. The highest total concentration of $5.87 \mathrm{E}-02 \mathrm{mg} / \mathrm{kg}$ was recorded in the liver, while the lowest total concentration of $1.87 \mathrm{E}-03 \mathrm{mg} / \mathrm{kg}$ was recorded in the intestine. Table 3 shows the mean concentrations of herbicide residues of different tissues of Synodentis budgetti from Alau Dam. The highest total concentration of $3.04 \mathrm{E}-02 \mathrm{mg} / \mathrm{kg}$ was recorded in the gills, while the lowest total concentration of $2.33 \mathrm{E}-03 \mathrm{mg} / \mathrm{kg}$ was recorded in the intestine. Table 4 shows the mean concentrations of herbicide residues in different tissues of Heterotis niloticus from Alau Dam. The highest total concentration of $3.74 \mathrm{E}-02 \mathrm{mg} / \mathrm{kg}$ was recorded in the liver, while the lowest total concentration of $2.35 \mathrm{E}-03 \mathrm{mg} / \mathrm{kg}$ was recorded in the intestine.

Table 1. Mean Concentration of Some Herbicide Residues (mg/kg) in Different Tissues of Tilapia zillii from Alau Dam.

\begin{tabular}{lllll}
\hline \multirow{2}{*}{ Herbicides } & \multicolumn{4}{l}{ Concentrations (mg/kg) } \\
\cline { 2 - 5 } & Liver & Flesh & Intestine & Gills \\
\hline Glyphosate & $5.22 \mathrm{E}-03$ & $1.92 \mathrm{E}-03$ & $4.03 \mathrm{E}-04$ & $9.87 \mathrm{E}-03$ \\
Butachlor & $9.17 \mathrm{E}-03$ & $2.32 \mathrm{E}-04$ & $5.04 \mathrm{E}-04$ & $7.87 \mathrm{E}-03$ \\
Metolachlor & $5.94 \mathrm{E}-03$ & $3.20 \mathrm{E}-03$ & $2.10 \mathrm{E}-04$ & $6.05 \mathrm{E}-03$ \\
Paraquat & $8.09 \mathrm{E}-03$ & $4.08 \mathrm{E}-04$ & $5.03 \mathrm{E}-04$ & $8.93 \mathrm{E}-03$ \\
Propachlor & $7.03 \mathrm{E}-03$ & $4.73 \mathrm{E}-04$ & $2.39 \mathrm{E}-04$ & $7.34 \mathrm{E}-03$ \\
Atrazine & $8.23 \mathrm{E}-03$ & $1.93 \mathrm{E}-04$ & $1.23 \mathrm{E}-04$ & $6.93 \mathrm{E}-03$ \\
Propanil & $5.93 \mathrm{E}-03$ & $2.83 \mathrm{E}-04$ & $1.09 \mathrm{E}-04$ & $8.11 \mathrm{E}-03$ \\
Alachlor & $6.03 \mathrm{E}-03$ & $4.05 \mathrm{E}-04$ & $2.19 \mathrm{E}-04$ & $7.04 \mathrm{E}-03$ \\
Total & $5.56 \mathrm{E}-02$ & $7.11 \mathrm{E}-03$ & $2.31 \mathrm{E}-03$ & $6.21 \mathrm{E}-02$ \\
\hline
\end{tabular}

Table 2. Mean Concentrations of Some Herbicide Residues (mg/kg) in Different Tissues of Clarias anguillaris from Alau Dam.

\begin{tabular}{lllll}
\hline \multirow{2}{*}{ Herbicides } & \multicolumn{4}{l}{ Concentrations (mg/kg) } \\
\cline { 2 - 5 } & Liver & Flesh & Intestine & Gills \\
\hline Glyphosate & $7.69 \mathrm{E}-03$ & $2.34 \mathrm{E}-04$ & $1.74 \mathrm{E}-04$ & $5.21 \mathrm{E}-03$ \\
Butachlor & $6.93 \mathrm{E}-03$ & $3.30 \mathrm{E}-04$ & $3.39 \mathrm{E}-04$ & $6.34 \mathrm{E}-03$ \\
Metolachlor & $8.34 \mathrm{E}-03$ & $2.23 \mathrm{E}-04$ & $1.98 \mathrm{E}-04$ & $3.29 \mathrm{E}-03$ \\
Paraquat & $8.00 \mathrm{E}-03$ & $1.93 \mathrm{E}-04$ & $1.93 \mathrm{E}-04$ & $1.03 \mathrm{E}-03$ \\
Propachlor & $6.34 \mathrm{E}-03$ & $3.29 \mathrm{E}-04$ & $2.54 \mathrm{E}-04$ & $2.19 \mathrm{E}-03$ \\
Atrazine & $7.03 \mathrm{E}-03$ & $1.64 \mathrm{E}-04$ & $1.84 \mathrm{E}-04$ & $4.21 \mathrm{E}-03$ \\
Propanil & $8.03 \mathrm{E}-03$ & $2.56 \mathrm{E}-04$ & $3.29 \mathrm{E}-04$ & $2.19 \mathrm{E}-03$ \\
Alachlor & $6.32 \mathrm{E}-03$ & $3.29 \mathrm{E}-04$ & $1.97 \mathrm{E}-04$ & $3.29 \mathrm{E}-03$ \\
Total & $5.87 \mathrm{E}-02$ & $2.06 \mathrm{E}-03$ & $1.87 \mathrm{E}-03$ & $2.78 \mathrm{E}-02$ \\
\hline
\end{tabular}

Table 3. Mean Concentrations of Some Herbicide Residues ( $\mathrm{mg} / \mathrm{kg}$ ) in Different Tissues of Synodentis budgetti from Alau Dam.

\begin{tabular}{lllll}
\hline \multirow{2}{*}{ Herbicides } & \multicolumn{4}{l}{ Concentrations $(\mathbf{m g} / \mathbf{k g})$} \\
\cline { 2 - 5 } & Liver & Flesh & Intestine & Gills \\
\hline Glyphosate & $3.29 \mathrm{E}-03$ & $4.39 \mathrm{E}-04$ & $1.93 \mathrm{E}-04$ & $7.98 \mathrm{E}-03$ \\
Butachlor & $2.19 \mathrm{E}-03$ & $3.29 \mathrm{E}-04$ & $1.22 \mathrm{E}-04$ & $5.44 \mathrm{E}-03$ \\
Metolachlor & $1.43 \mathrm{E}-03$ & $1.93 \mathrm{E}-04$ & $5.39 \mathrm{E}-04$ & $2.65 \mathrm{E}-03$ \\
Paraquat & $3.29 \mathrm{E}-03$ & $2.12 \mathrm{E}-04$ & $2.84 \mathrm{E}-04$ & $2.92 \mathrm{E}-03$ \\
Propachlor & $2.54 \mathrm{E}-03$ & $4.39 \mathrm{E}-04$ & $2.20 \mathrm{E}-04$ & $1.98 \mathrm{E}-03$ \\
Atrazine & $1.54 \mathrm{E}-03$ & $2.19 \mathrm{E}-04$ & $1.93 \mathrm{E}-04$ & $4.29 \mathrm{E}-03$ \\
Propanil & $2.34 \mathrm{E}-03$ & $5.93 \mathrm{E}-04$ & $2.81 \mathrm{E}-04$ & $2.10 \mathrm{E}-03$ \\
Alachlor & $2.34 \mathrm{E}-03$ & $3.29 \mathrm{E}-04$ & $4.98 \mathrm{E}-04$ & $3.02 \mathrm{E}-03$ \\
Total & $1.90 \mathrm{E}-02$ & $2.75 \mathrm{E}-03$ & $2.33 \mathrm{E}-03$ & $3.04 \mathrm{E}-02$ \\
\hline
\end{tabular}

Table 4. Mean Concentrations of Some Herbicide Residues in Different Tissues of Heterotis niloticus from Alau Dam.

\begin{tabular}{lllll}
\hline \multirow{2}{*}{ Herbicides } & \multicolumn{4}{l}{ Concentrations (mg/kg) } \\
\cline { 2 - 5 } & Liver & Flesh & Intestine & Gills \\
\hline Glyphosate & $4.38 \mathrm{E}-03$ & $2.98 \mathrm{E}-04$ & $1.76 \mathrm{E}-04$ & $5.09 \mathrm{E}-03$ \\
Butachlor & $3.99 \mathrm{E}-03$ & $1.87 \mathrm{E}-04$ & $3.95 \mathrm{E}-04$ & $1.77 \mathrm{E}-03$ \\
Metolachlor & $4.87 \mathrm{E}-03$ & $6.98 \mathrm{E}-04$ & $2.53 \mathrm{E}-04$ & $3.99 \mathrm{E}-03$ \\
Paraquat & $2.99 \mathrm{E}-03$ & $2.42 \mathrm{E}-04$ & $1.99 \mathrm{E}-04$ & $5.23 \mathrm{E}-03$ \\
Propachlor & $1.93 \mathrm{E}-03$ & $3.29 \mathrm{E}-04$ & $2.04 \mathrm{E}-04$ & $1.09 \mathrm{E}-03$ \\
Atrazine & $4.93 \mathrm{E}-03$ & $1.03 \mathrm{E}-04$ & $1.93 \mathrm{E}-04$ & $6.76 \mathrm{E}-03$ \\
Propanil & $8.33 \mathrm{E}-03$ & $2.93 \mathrm{E}-04$ & $7.33 \mathrm{E}-04$ & $4.98 \mathrm{E}-03$ \\
Alachlor & $5.94 \mathrm{E}-03$ & $5.11 \mathrm{E}-04$ & $1.97 \mathrm{E}-04$ & $3.33 \mathrm{E}-03$ \\
Total & $3.74 \mathrm{E}-02$ & $2.66 \mathrm{E}-03$ & $2.35 \mathrm{E}-03$ & $3.22 \mathrm{E}-02$ \\
\hline
\end{tabular}

Table 5 shows the total concentrations of herbicide residues in different fish samples (Tilapia zillii, Clarias anguillaris, Synodentis budgetti and Heterotis niloticus) from Alau Dam. The concentration of glyphosate ranges from 9.94E-03 to $1.74 \mathrm{E}-02 \mathrm{mg} / \mathrm{kg} ; 6.34 \mathrm{E}-03$ to $1.78 \mathrm{E}-02 \mathrm{mg} / \mathrm{kg}$ butachlor; $4.81 \mathrm{E}-03$ to $1.54 \mathrm{E}-02 \mathrm{mg} / \mathrm{kg}$ metolachlor; $6.71 \mathrm{E}-$ 03 to $1.79 \mathrm{E}-02 \mathrm{mg} / \mathrm{kg}$ paraquat; $3.55 \mathrm{E}-6.24 \mathrm{E}-03$ to $1.55 \mathrm{E}-02$ $\mathrm{mg} / \mathrm{kg}$ atrazine; $5.31 \mathrm{E}-03$ to $1.44 \mathrm{E}-02 \mathrm{mg} / \mathrm{kg}$ propanil and $6.19 \mathrm{E}-03$ to $1.37 \mathrm{E}-02 \mathrm{mg} / \mathrm{kg}$ alachlor. The highest total concentrations of all the studied herbicide residues were detected in Tilapia zillii, follow by Clarias anguillaris, while Synodentis budgetti shows the lowest values.

Table 5. Total Concentrations (mg/kg) of Some Herbicide Residues in Different Species of Fish Samples.

\begin{tabular}{lllc}
\hline Concentrations (mg/kg) & & & \\
\hline Herbicides & Tilapia zillii & Clarias anguillaris & Synodentis budgetti \\
\hline Glyphosate & $1.74 \mathrm{E}-02$ & $1.33 \mathrm{E}-02$ & $1.19 \mathrm{E}-02$ \\
Butachlor & $1.78 \mathrm{E}-02$ & $1.39 \mathrm{E}-02$ & $8.08 \mathrm{E}-03$ \\
Metolachlor & $1.54 \mathrm{E}-02$ & $1.21 \mathrm{E}-02$ & $4.81 \mathrm{E}-03$ \\
Paraquat & $1.79 \mathrm{E}-02$ & $9.42 \mathrm{E}-03$ & $6.71 \mathrm{E}-03$ \\
Propachlor 03 & $9.11 \mathrm{E}-03$ & $5.18 \mathrm{E}-03$ \\
Atrazine & $1.51 \mathrm{E}-02$ & $1.16 \mathrm{E}-02$ & $6.24 \mathrm{E}-03$ \\
Propanil & $1.55 \mathrm{E}-02$ & $1.08 \mathrm{E}-02$ & 5.03 \\
Alachlor & $1.44 \mathrm{E}-02$ & $1.01 \mathrm{E}-02$ & $3.55 \mathrm{E}-03$ \\
\hline
\end{tabular}

Figure 1 shows the concentration of some herbicide residues in the liver of the studied fish samples. The liver of Tilapia zilli and Clarias angullaris shows the most dominant levels of all the studied herbicides, while Synodentis budgetti shows the lowest values. For that of flesh and gills samples, Tilapia zilli was observed to show the highest levels of all the studied herbicides, while Clarias angullaris shows the lowest values Figure 2, 3 and 4. 


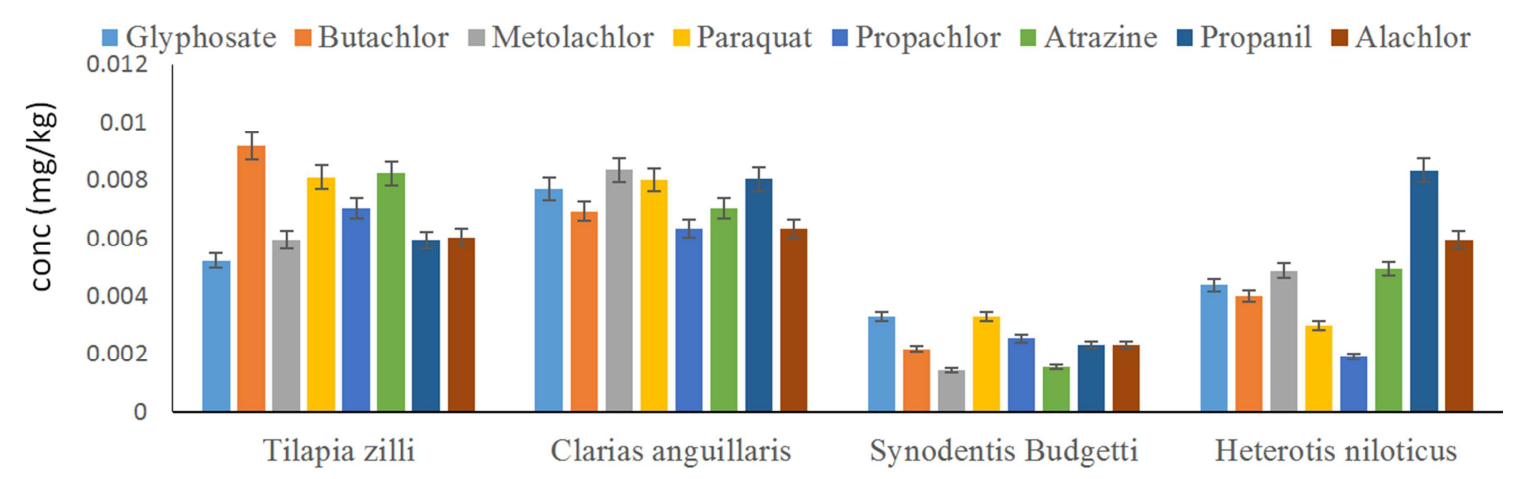

Figure 1. Comparison in Concentrations of Herbicide Residues between Liver of Four Species of Fish Samples from Gubi Dam, Bauchi State, Nigeria.

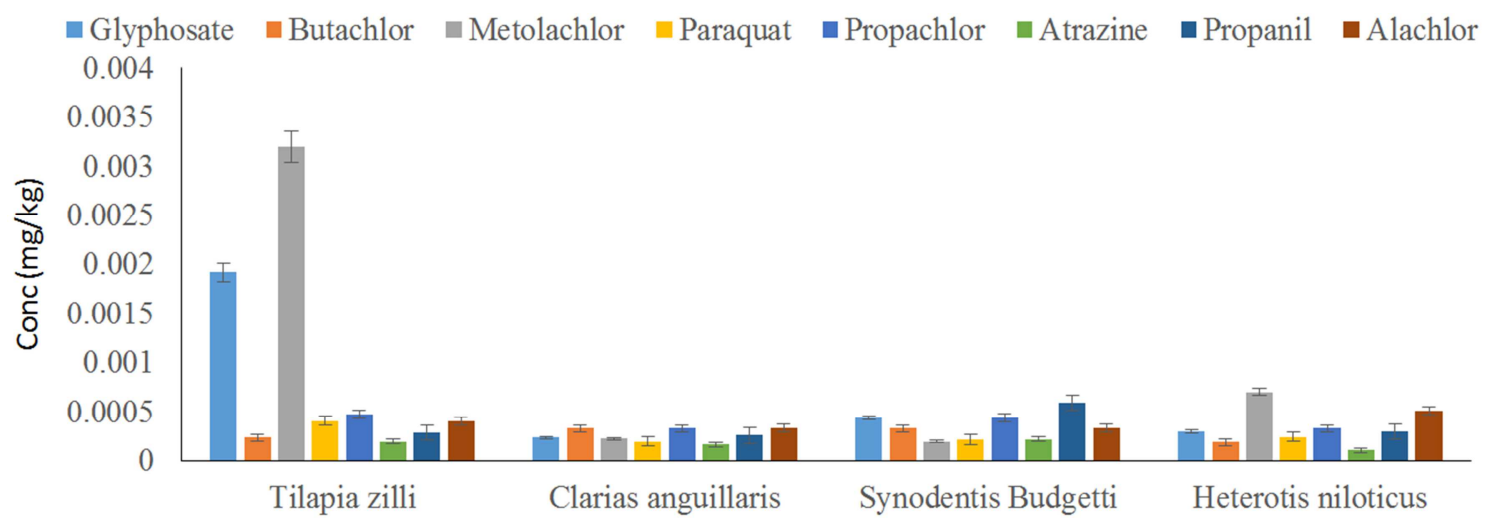

Figure 2. Comparison in Concentrations of Herbicide Residues between Flesh of Four Species of Fish Samples from Alau Dam.

$\square$ Glyphosate $\backsim$ Butachlor $\square$ Metolachlor $\square$ Paraquat $\square$ Propachlor $\square$ Atrazine $\square$ Propanil $\square$ Alachlor

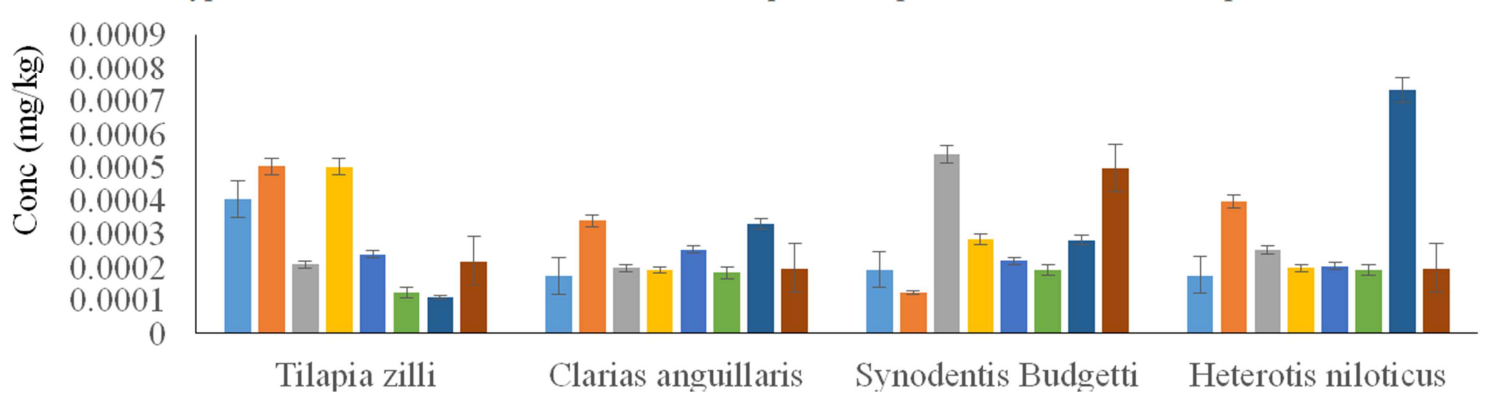

Figure 3. Comparison in Concentrations of Herbicide Residues between Intestine of Four Species of Fish Samples from Alau Dam.

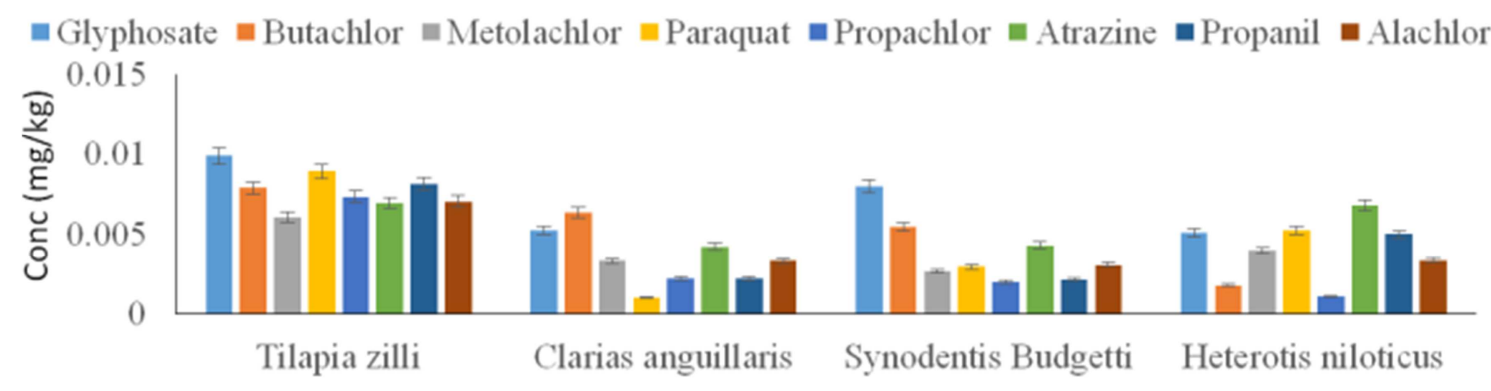

Figure 4. Comparison in Concentrations of Herbicide Residues between Gills of Four Species of Fish Samples from Alau Dam.

\section{Discussion}

Results of the present study are in agreement with that [14], where he explain that herbicides tend to accumulate in living organisms especially in aquatic organisms and they substantially settle on the sediments. The highest value of glyphosate was observed in the gills of Tilapia zilli, while the lowest value was observed in intestine of Heterotis niloticus. Despite the adverse side effect of herbicide, herbicides form an integral component of modern agriculture practice all over the world. The benefits are increase supply of food, but problems arise when significant amount of the chemicals are left on the field as residue which tend to affect non target organisms and river bodies are one of the main recipient of 
herbicide as a residues generated on the field. The concentrations of atrazine were significantly higher in the liver of the four species of fish study. In the present study the highest concentration of atrazine was observed in the liver of Clarias gariepinus with a value of $8.23 \mathrm{E} 0-3 \mathrm{mg} / \mathrm{kg}$, while the flesh of Heterotis niloticus shows the lowest value of $1.03 \mathrm{E}-$ $04 \mathrm{mg} / \mathrm{kg}$. The high levels of atrazine in the liver might be attributed to the fact that liver as a storage organ for vast variety of nutrient. The concentration of butachlor and alachlor were higher in the liver of Tilapia zilli, while the flesh and intestine shows the lowest value. A study carried outby [15] shows that butachlor poses potential threat to the aquatic ecosystem. Researcher [16] studied the toxic effects of butachlor in fish and daphnia and other aquatic organisms and their study shows high toxicity of herbicides. A study [17] also reported that the residues of butachlor in paddy field, even though lower than the safe concentration, caused toxic effect to Cyprinus carpio. In another study, butachlor was found to cause remarkable protein loss in Clarias batrachus at both lethal and sub-lethal concentration which might be due to increased proteolysis [18] or by metabolic utilization of ketoacids to glucogenesis pathway for synthesis of glucose [19]. The above results demonstrated adverse effects of butachlor on the normal reproductive process of zebra fish and also found to disrupt the thyroid and sex steroid endocrine systems when exposed to butachlor for 30 days [20]. Results from the present study show that, the maximum concentration of $9.17 \mathrm{E}-03 \mathrm{mg} / \mathrm{kg}$ was detected in Tilapia zilli, which is in comformity with study conducted [21], which revealed levels of butachlor in all the fish samples analyst. This study is in agreement with the study carried out [22], which revealed some levels of insecticide residues in tissues of fish samples from Alau Dam, Maiduguri, Borno State Nigeria. The highest mean concentration of $8.93 \mathrm{E}-03 \mathrm{mg} / \mathrm{kg}$ paraquat in the present study was detected in the gills of the Tilapia zilli. Irrespective of the route of administration of herbicides in mammalian systems, paraquat is rapidly distributed in most tissues, with the highest concentration found in the lungs and kidneys [23]. This trend contradicts the present study, were the concentrations of paraquat was significantly higher in the liver and gills. Generally, the studied herbicide residues in the fish samples were higher in the liver and gills of all the fishes studied when compared with other organs. The high level of these herbicides in the liver and gills might be due to the fact that fresh water fishes gills might be expected to be the primary route for the uptake of water pollutants; while the liver serve as a storage organs for vast variety of nutrient. High accumulation of these herbicides in the gills and liver can also be as a result of detoxicating mechanisms and may originate from herbicides deposited in the sediments and food in the aquatic environment as reported [24]. However, the liver is the preferred organ for pollutants accumulation as could be deduced from the present study which is in line with the study carried out [25], which revealed that the exposure of fish to herbicide increased in the size of lipid droplets, vacuolization in the liver. Accumulation of herbicides in different species is the function of their respective membrane permeability and enzyme system, which is highly species specific and because of the fact that herbicide residues accumulated in different organs in the fish as observed in the study. The present study revealed that herbicide accumulation in tissues of fish samples were in order of liver $>$ gills $>$ intestine $>$ flesh, this research work is in agreement with the study carried out [24, 26, 27] which revealed that the variations in the residue analysis are due to factors like difference in uptake rate, lipid content of respective animal tissue, chemical structure, solubility, and metabolic pattern. The concentrations of the studied herbicides in the fish samples were observed to be lower than the WHO and FAO [28] set maximum residue limit (MRL) $0.01 \mathrm{mg} / \mathrm{kg}$ and the Acceptable Daily Intake value (ADI) of $0.006 \mathrm{mg} / \mathrm{kg}$ which is considered safe for consumption as at the time of the present research work.

\section{Conclusion}

The observed concentrations of the studied herbicides in the fish samples suggest a relatively clean aquatic environment that has not yet been significantly contaminated by herbicide residues. But their presence in the fish samples also cause for concern, therefore, it is important for relevant agencies to be involve in the management of Alau Dam with respect to herbicides residues.

\section{Acknowledgements}

Authors gratefully thank the full financial support from TetFund (Tertiary Educational Trust Fund, Nigeria) through University of Maiduguri Management (Tetfund/ DESS/ UNI/ MAIDUGURI/ RP/ VOL. II).

\section{References}

[1] Hayes, T., Haston, K., Tsui, M., Hoang, A., Haeffele, C. and Vonk, A. (2003). Pesticide Mixtures, Endocrine Disruption and Amphibian Declines. Environmental Health Perspective, 111: 568-575.

[2] Abhilash, P. C. and Singh, N. (2009). Pesticide use and application: an Indian scenario. Journal of Hazardous Materials, 165: 1-12.

[3] Williamson, S., Ball, A. and Pretty, J. (2008). Trends in Pesticide Use and Drivers for Safer Pest Management in Four African Countries. Crop Protection, 27: 1327-1334.

[4] Nilufar, F. (2005). Fate and transport of herbicides in soil in the presence of surfactants in irrigation water. MSc thesis, Canada, November, 1-120.

[5] Ghosh, P. K. and Philip, L. (2006). Environmental Significance of Atrazine in Aqueous Systems and its Removal by Biological Processes, Global Nest Journal, 8 (2): 159-178.

[6] Battaglin, W. and Fairchild, J. (2002). Potential toxicity of pesticides measured in Midwestern streams to aquatic organism. Water Science and Technology, 45 (9): 95-103. 
[7] Perez-Ruzafa, A., Navarro, S., Marcos, C., Camara, M. A., Salas, F. and Gutierrez, M. (2000). Presence of Pesticides throughout Trophic Compartments of the Food Web in the Mar Menor Lagoon (SE Spain). Marine Pollution Bulletin, 40 (2): 140-15.

[8] Zbytniewski, R. and Buszewski, B. (2002). Sorption of Pesticides in Soil and Compost, Polish Journal of Environmental Studies, 119 (20): 179-184.

[9] Ezemonye, I. and Tongo. (2009) Lethal and sublethal effects of atrazine to amphibian larvae Jordan. Jounal of Biological Science, 1: 29-36.

[10] Hopenhayn-rich, M. L. and Stump, S. R. (2001). Browning Regional assessment of Atrazine exposure and incidence of breast and ovarian cancers in Kentucky Arch. Environmental Contamination and Toxicology, 42: 127-136 L. I. N.

[11] Peighambarzadeh, Z., Safi, S., Shahtaheri, S. J., Javanbakht, M. and Forushani, A. R. (2011) Presence of atrazine in the biological samples of cattle and its consequence adversity in human health. Iranian Journal of Public Health, 4: 12-121.

[12] Zheng, J., Li, R., Zhu, J., Zhang, J., He, J., Li, S. and Jiang, J. (2012) Degradation of the chloroacetamide herbicide butachlor by Catellibacteriumcaeni sp. nov DCA-1T. International Biodeterioration and Biodegradation, 73: 1622.

[13] Paula, P., Michelangelo, A., Dorothea, M., Irina, S., Bünyamin, T., José, O. and Alberto, B. (2007). Analysis of pesticide residues using the Quick Easy Cheap Effective Rugged and Safe (QuEChERS) pesticide multiresidue method in combination with gas and liquid chromatography and tandem mass spectrometric detection. Analytical and Bioanalytical Chemistry, 389 (6): 1697-714.

[14] Kammann, U., landgraff, O. and Steinhart, H. (1992). Cyclic Organochlorines in benthic organisms from the North Sea and the German Bight. Analysis Magazine, 20: 70-73.

[15] He, H., Chen, G., Yu, J., He, J., Huang, X., Li, S., Guo, Q., Yu, T. and $\mathrm{Li}, \mathrm{H}$. (2013). Individual and joint toxicity of three chloroacetanilide herbicides to freshwater cladoceran Daphnia carinata. Bulletin of Environmental Contamination and Toxicology, 90: 344-350.

[16] Hashimoto, Y and Y. Nischituchi (1983). IUPAC Pesticides chemistry, human welfare and the environment. (Eds.: J Miyamoto and PC Kearney), Pergamon Press, New York, 2: 355-358.

[17] Wang, S., Cheng, C. C., Liu, H. and Chiangh, C. (1991). Residue of three herbicides in paddy water and their danger level to carp. Journal of China Agricultural Chemical Sociology, 29 (2): 195-202.
[18] Muley, D. V., Karanjkar, D. M. and Maske, S. V. (2007). Impact of industrial effluents on the biochemical composition of freshwater fish Labeo-rohita. Journal of Environmental Biology, 28 (2): 245-249.

[19] Rajput, V., Singh, S. K., Kirti, A. and Abhishek, (2012). Comparative toxicity of Butachlor, Imidacloprid and Sodium fluoride on protein profile of the walking cat fish Clarias batrachus. Journal of Applied Pharmaceutical Science, 2 (6): 121-124.

[20] Chang, J., Liu, S., Zhou, S., Wang, M. and Zhu, G. (2013). Effects of butachlor on reproduction and hormone levels in adult zebrafish (Daniorerio). Experimental Toxicology and Pathology, 65: 205-209.

[21] Yadav, A., Bhatnagar, A. and Kaur, M. (2013). Aberrations in the Chromosomes of Cirrhinus mrigala (Hamilton) upon exposure to Butachlor. Iranian Journal of Toxicology, 7 (21): $858-865$.

[22] Akan, J. C., Mohammed, Z., Jafiya. and Ogugbuja, V. O. (2013). Organochlorine pesticide residues in fish samples from Alau Dam, Borno State, North Eastern Nigeria. Journal of Environmental and Analytical Toxicology, 3: 171.

[23] Suntres, Z. E. (2002). Role of antioxidants in paraquat toxicity. Toxicology, 180 (1): 65-77.

[24] Akan, J. C., Abdulrahman, F. I. and Chellube. Z. M. (2014). Organochlorine and Organophosphorus Pesticide Residues in Fish Samples from Lake Chad, Baga, North Eastern Nigeria International Journal of Innovation, Management and Technology, Vol. 5, No. 2.

[25] Risbourg, S. B. and Bastide, J. (1995). Hepatic perturbations induced by a herbicide (atrazine) in juvenile grey mullet Liza ramada (Mugilidae Telostei): an ultra-structural study. Aquatic Toxicology, 31: 217-229.

[26] Tilak, K. S., Satyavardhan, K. and Thathaji, P. B. (2003). Biochemical changes induced by fenvalerate in the freshwater fish Channa punctata. Journals of Ecotoxicology Environmental Monitoring. 13 (4): 261-270.

[27] Tilak, K. S., Veeraiah, K. and Koteswara, Rao, D. (2004). Toxicity and bioaccumulation of chlorpyrifos in Indian carp Catla catla (Ham.), Labeo rohita (Ham.) and Cirrhinus mrigala (Ham.). Bulletin of Environmental Contamination Toxicology, 3 (5): 933-941.

[28] Codex, Alimentarius Commission (2009). Pesticide residue in food and feed. Extraneous Maximum Residue Limits. Greenwood Publishing group. 